\title{
South Africa 2018: Mandela's memory and presidential prototypes for exercise interventions and implementation
}

\author{
Jon Patricios ${ }^{1,2}$
}

\begin{abstract}
"Even (in prison) on Robben island, I attempted to follow my old boxing routine of doing roadwork and muscle-building... On Monday through Thursday, I would do stationary running in my cell in the morning for up to forty-five minutes. I would also perform one hundred fingertip push-ups, two hundred sit-ups, fifty deep knee-bends, and various other calisthenics." Nelson Mandela: Long Walk to Freedom, $1994^{1}$
\end{abstract}

This year South African icon Nelson Mandela would have turned a hundred. International Nelson Mandela Day, a tribute to the icon's attributes, is on 18 July. Mandela was a great advocate of exercise as part of a holistic approach to life and maintained a regular exercise routine from his days as a student, during his time in prison, throughout his political career and into retirement. As the inset on the cover of this SASMA edition illustrates, Mandela had a passion for boxing. 'I did not enjoy the violence of boxing so much as the science of it." Along with the commemorative lectures, coins and celebrations planned in $2018,{ }^{2}$ we should also be inspired by Mandela the athlete.

South Africa's newly inaugurated president, Cyril Ramaphosa, has picked up on the exercise theme. He has encouraged the public to join him on his morning walks setting Twitter abuzz with the hashtag \#TummyMustFall earning himself the nickname "Runner-phosa". 3

With all these active South Africans pouring onto the streets and into parks, the sports medicine community had better be equipped to dispense appropriate advice. Hopefully this edition of BJSM will assist as we explore a theme of 'Implementation: what really works in clinical practice?'

\footnotetext{
${ }^{2}$ Department of Emergency Medicine, Faculty of Health Sciences, University of the Witwatersrand, Johannesburg, South Africa

${ }^{1}$ Section of Sports Medicine, Faculty of Health Sciences, University of Pretoria, Johannesburg, South Africa

Correspondence to Dr Jon Patricios and Dr Jon Patricios, Section of Sports Medicine, Faculty of Health Sciences, University of Pretoria, Johannesburg, 2121, South AfricaSection of Sports Medicine, Faculty of Health Sciences, University of Pretoria, Johannesburg, 2121, South Africa; jpat@mweb.co.za, jpat@mweb.co.za
}

Martin Raftery, CMO of World Rugby deserves credit for initiating a meeting of medical representatives across contact and collision sporting codes in Dublin, August 2017. The 'concussion implementation' paper in this edition summarises eight key areas of discussion between codes and provides a 'best practice' guide to implementing the Berlin consensus guidelines (see page 636). Perhaps Mandela would be disappointed that boxing is not represented among the 11 international sports associations. Certainly FIFA, as one of the world's most influential sports governing bodies, is conspicuous by its absence from the paper.

Being inspired by presidential examples

Mandela brought out the humanity in all of us (revisit South African@DrPauIDijkstra's blog 'What if Nelson Mandela was a sports medicine physician?'). ${ }^{5}$ Cyril Ramaphosa has given daily exercise presidential endorsement as he emulates the great man. An informed human touch will always trump a stencilled and mechanical approach to medicine. The excellent papers in this edition remind us of the importance of human clinical intervention in identifying and managing a range of exercise-related conditions using an evidence-based, education-inspired and clinician-communicated approach that is optimal for athlete patient care. In the South Africa of 2018, we are inspired by our memories and motivated by positive example. times the incidence of pain, degenerative disease and knee replacements. They'd do well to read Zeng et al's paper on the efficacy of topical anti-inflammatories in osteoarthritis (see page 643).

....and hamstring hassles

Young $\mathrm{PhD}$ researcher Nick van der Horst defines return-to-play after hamstring injury and lists the important inclusion criteria in making a RTP decision (see page 685). No, it's not a normal MRI scan. Read on...

Still on the theme of muscle injuries Büttner et al revisit the concept of a muscle injury registry and present an (African-inspired?) 'Big Five' of consensus considerations(see page 630).

Tendinopathy management is an area regularly featured in BJSM. The themes of beneficial tissue loading and resultant changes from mechanotransduction are consistent, but Rio and Docking remind us that exercising an injured tendon has more benefits than just changes to local tissue structure (see page 622). Central nervous system changes and structural muscle adaptations may be equally important and occur much earlier in the process.

Berlin concussion: consistent implementation across sporting codes

\section{Competing interests None declared.}

Provenance and peer review Commissioned; internally peer reviewed.

C Article author(s) (or their employer(s) unless otherwise stated in the text of the article) 2018. All rights reserved. No commercial use is permitted unless otherwise expressly granted.

\section{Check for updates}

To cite Patricios J. Br J Sports Med 2018;52:621.

Br J Sports Med 2018;52:621

doi:10.1136/bjsports-2018-099270

\section{REFERENCES}

1 Mandela, Nelson, 1918-2013. Long Walk to Freedom. New York: Flash Point/Roaring Brook Press, 2009.

2 Nelson Mandela Foundation.

https://www.nelsonmandela.org

3 Eye Witness News. 'The tummy must fall': Ramaphosa encourages healthy living on morning walk. http://ewn. co.za/2018/02/20/the-tummy-must-fall-ramaphosaencourages-healthy-living-on-morning-walk

4 Taunton JE, Ryan MB, Clement DB, et al. A retrospective case-control analysis of 2002 running injuries. $\mathrm{Br} J$ Sports Med 2002;36:95-101.

5 Guest Blog: What if Nelson Mandela was a Sports Medicine Physician? by @DrPaulDijkstra.Br J Sport Med http://blogs.bmj.com/bjsm/2013/12/07/guest-blog-whatif-nelson-mandela-was-a-sports-medicine-physician-bydrpauldijkstral 